\title{
Actors' Role in Public Asset Management A Study of Limboto Lake in Gorontalo, Indonesia
}

\author{
Trisusanti Lamangida \\ Department of Public Administration \\ Muhammadiyah University of Gorontalo \\ Gorontalo, Indonesia \\ tri.susanti@um-gorontalo.ac.id \\ Haedar Akib \\ Department of Public Administration \\ State University of Makassar \\ Makassar, Indonesia
}

\author{
Muh. Firyal Akbar \\ Department of Public Administration \\ Muhammadiyah University of Gorontalo \\ Gorontalo, Indonesia \\ firyalakbar@umgo.ac.id \\ Muh. Aswar \\ Department of English Education \\ Muhammadiyah University of Makassar \\ Makassar, Indonesia \\ muhammad.ashwark@gmail.com
}

\begin{abstract}
Government, 2) Private Sector, and 3) Society. They had the role and function in answering public's questions and became a motor of development in providing solutions especially in asset management of Limboto Lake. Lake Rescue had made either through academic research, community empowerment, and FGD by various agencies until the signing the MoU between local government and city in $\mathbf{2 0 0 6}$. However, it was considered too late to follow-up. The Implementation of Regulation No. 1 of 2008 on the Limboto Lake management had not accompanied by concrete efforts, effectively and continuously by the government, society, or even private sector. The political administration aspects of Japesda Gorontalo showed that the management of Lake Rescue was not done in isolation. The public's role was needed in ranging program planning; regulation, control, and preservation as an essential part in managing Limboto Lake. This study aimed to identify and describe the role of three actors in the management of public assets Limboto Lake. Tis study use case study approach. The research location was in Limboto Lake of Gorontalo. The technique of collecting data was observation, interview, and documentation. The Data analysis began with reduction of data; presenting data and conclusion. The results showed that the sector's role in public assets management of Limboto Lake had not been based on New Public Management (NPM) which increased the social development, science, and technology. The Lack of information hindered the sector's role and government's relationship with public and private sectors to improve the policy that public needed.
\end{abstract}

Keywords: policy actor; asset management; public asset; Gorontalo; Limboto Lake

\section{INTRODUCTION}

The phenomenon of Limboto lake today is increasingly concerned and needs attention from various parties. The three pillars of development that play a role in development are 1) government, 2) private sector, 3) society. These three things have a role and function in answering public problems as well as being the motor of development in providing solutions related to asset management, especially public management of Limboto lake. The ongoing process of silting Limboto lake raises concerns about the fate of the lake in the future.
Limboto lake has recorded history which provides welfare for people in Gorontalo because most $(60 \%)$ people rely on this freshwater wealth but the fact, it instead becomes a source of misery. In the rainy, it always floods and in the dry season, Gorontalo has not enough water for drinking and agriculture due to drought. Lake rescue efforts have been made either through academic research, community empowerment by NGOs through the utilization of water hyacinth, and focused group discussion by various agencies in the government level Gorontalo province, until the signing of the MoU management agreements Limboto Lake, between the government city and the district government of Gorontalo in 2006 before the Governor of Gorontalo and the Minister of the Environment. However, it is considered too late to follow-up from the time lost. Implementation Regulation No. 1 of 2008 on managing Limboto Lake has not been accompanied by concrete efforts, effectively and continuously by the stakeholders, the public, especially the private sector [1]. Aspects of the political administration (Bioregionalism approach) proposed by the Supervisory Board of Japesda Gorontalo shows that managing Limboto Lake in the rescue efforts was not done in isolation [2] The role of public actors in managing Limboto Lake is needed, ranging from program planning; regulation, control, and preservation of the Limboto Lake can become an essential part of the management public asset study in managing Limboto Lake. This study aims to identify and describe the role of the three sectors in the management of public assets Limboto Lake.

\section{RESEARCH METHOD}

The method used is a type of qualitative case study approach. Generally, the case study approach research belongs to the type of qualitative research because it is done thoroughly and profoundly. The Instrument research tool used in the study interview guides. The research location is Limboto lake of Gorontalo. Research instrument is the researchers themselves, aided by research tools. The data source consists of primary data and secondary data. The data analysis technique begins with the reduction of data, 
presenting data, and conclusion are carried out simultaneously with the process of data collection [3]

\section{RESULT AND DISCUSSION}

Based on the results of the research that obtained through interviews, observation and documentation showed that the role of government in managing lake as a form of rescue effort Limboto Lake has not integrated planning. The role of the government as a determinant and policymaker in making the local regulation related to Limboto lake management has not been effective. The Local Government either provincial or regency is not maximal in managing Limboto Lake. The government should be able to create a stable political and social-economic condition especially in addressing the existence and uniqueness of Limboto lake that has served a million benefits and potential as a major contribution to the livelihood of coastal communities Limboto lake but this did not happen. First observations and interviews with informants and secondary data collected indicate that the government's role in creating such political, social and economic conditions in the planning, regulation, control and reservation activities of Limboto Lake does not work as mandated in the 1945 Constitution article 33, in particular, paragraph 3 which states that the earth's water and natural resources contained therein are maintained by the State and used for the greatest prosperity of the people. The role of the private sector in running the business industry is not in favor of the people, especially to the public interest. The private sector should be able to create jobs by utilizing human resources on the coast of Limboto lake, but this did not happen. The private sector that is expected to improve people's living standard and maintain the environment is still a parable between dream and hope. The existence of the private sector at Gorontalo especially in Limboto Lake management is generally still partial and only concerned with corporate profits. According to one research informant that the role of the private sector, especially in managing Limboto lake still need to be encouraged and nurtured. The role of the community itself should be able to influence the process of public policy making, in particular, the management policy of Limboto Lake is still impressed and powerless. The management of Limboto Lake still creates problems every year. when the rainy season, floods often become a source of disaster, and when the dry season, clean water supply is threatened, even drought farming is feared will adversely affect the performance of food supply of Gorontalo Province. The community as an object and subject of development should play a role in accommodating and finishing public policy, especially in program planning and development supervision as well as a means of government check and balance in Limboto lake management. But the reality of the research findings showed that the people were only given the opportunity to play a participation role in attending meetings, workshops, seminars on lake management. Meanwhile, it gives rise to the apathy of the people who feel that they are needed only to come, sit and listen to the seminar activities and the workshop is guaranteed to get money. Ironically the implementation of the activities that formulating Lake Problem is actually implemented in luxury star building that is not suitable for the reconstruction object of the problem being discussed. Management of Limbo
Lake has become a National strategic area that should be communicating between members of the community for protecting the society's right. In fact, the role of the community has been represented only by legislators and NGOs, sometimes from NGO members themselves apathetic with the Limboto lake management program due to their dissatisfaction with the government in implementing the work program. The public administration paradigm that emphasizes on The New Public Management (NPM), which in its development follows the development of social life is progressively increasing and consequently in developing science and technology. The paradigm of New Public Management (NPM) is still a mere rhetoric not entirely implemented in the development process, especially in managing Limboto Lake. Based on the focus of research that aims to describe and illustrate the role of three sectors in managing public assets of Limboto Lake which based on indicators of the research, program planning, regulation, control, and preservation management Limboto Lake can be described as follows:

\section{A. Planning}

Planning, utilization and development control of various sectors including strategic environmental sectors that directly impact on the management of Limboto Lake, by playing the role of government, the private sector and society have not been sustainable and pro-environment. Moreover, it impresses the program planning that is partial and tends to be sectoral. Great opportunities for local revenue generation will be realized when managing Limboto Lake is conducted in partnership between these three pillars of development by playing its role. The magnitude of the gap that reflects the role of the government seemed rigid and less innovative and even unable to read the opportunities from the potential management of Limboto Lake. Creating the effective and accountable public service in planning policy, arrangement, execution, controlling, even reservation, management policy of Limboto Lake as regulated in Local Regulation no. 1 of 2008 is still not optimal. The ineffectiveness of managing Limboto Lake is due to the fact that Gorontalo Province within 5 (five) years of the defensive leadership period is still focused on improving the organizational structure and provision of government infrastructure facilities. The local government of Gorontalo regency itself has difficulty in solving the problems due to the dominant factors that are the lack of operational funds and the lack of socialization to society about the importance of public participation in managing Limboto Lake. The high political interests and the emphasis on performance accountability to fulfill the needs of external supervision makes the local governments hard to involve various parties (private, NGOs, and communities) in collaborative planning as expected in the application of governance concepts. Thus, the public asset management activities of the regional government of Gorontalo, especially on Limboto Lake management program plan, have not been optimal in involving the inter-governmental, private, and communities participation collaboratively. 


\section{B. Regulation}

Government Regency's role of Gorontalo in protecting the environment concretely has not been supported by the work program that regulates managing Limboto Lake in particular. Programs set forth in the form of RPJM and RPJP, are environmental conservation programs including Limboto Lake rescue, technically handled by respective SKPD. However, the compilation of the work program has not fully referred to Law No. 25 of 2004, on National Development Planning System (NDPS) [4], and Government Regulation No. 8 of 2008, on Stages, Procedures for Formulating, Controlling and Evaluating the Implementation of Regional Development Plan [5]. The provisions', regulating strategic environmental conservation activities such as Limboto Lake, involves various elements of local stakeholders in each process of preparation of the stages of regional development activities.

Regulation of Minister of Home Affairs No. 26/2006 on Guidelines for Formulating regional income and expenditure budgets 2007 [6], which is updated annually, it also regulates development plan that emphasizes political, technocratic, participatory, bottom-up and topdown approach. Therefore, the arrangement in managing Limboto Lake involves various institutions and obliges the role of the community actively. The Regulation of Minister of Home Affairs is implemented through Gorontalo Provincial Regulation No. 1 of 2008, on managing Limboto Lake.

Although there is a legal basis governing managing Limboto Lake, there is no indication of any real role between Gorontalo Provincial Government, Gorontalo District Government, Private, and Society in collaboration to regulate various matters relating to managing Limboto Lake. Management of Limboto Lake has not involved stakeholders such as elders in the agreement signed by Gorontalo District Government and Gorontalo City, and Gorontalo Provincial Government. The regulation on Limboto Lake management is done by Gorontalo Provincial Government through Local Regulation No. 4 of 2011, on Gorontalo Provincial Spatial Plan 2010-2030 $[7]^{8}$, which essentially emphasizes the integration of the program in the regional development process. However, the public asset management activities of the Regional Government of Gorontalo, in terms of managing Limboto Lake have not been able to engage the inter-governmental, private, and community collaborative roles.

\section{Controlling}

The Regional Government's role of Gorontalo has not specific program control that concerning on managing Limboto Lake. The restraint for saving Limboto Lake has been programmed by the Gorontalo Provincial Government. It relates to the local budget through strategic environmental assessment, which has been prepared based on the mandate of Law No. 32 of 2009 on Environmental Protection and Management [8]. The reality, it is not mandated by the Law, the National Development Planning System (NDPS). In the provisions of Chapter II of Article II, paragraph 4, explicitly states that the objectives of national development planning support the coordination between development actors, ensuring the creation of integration, synchronization and synergy between regions, space, time, the function of the Central and Regional government, ensuring linkages and consistency between planning, budgeting, implementation and oversight, optimizing community participation, and ensuring the use of resources in an efficient, effective, equitable and sustainable, Constitution No 25, 2004.

Similarly, the Minister of Home Affairs Regulation No. 67 of 2012, on the Guidelines for Strategic Environmental Assessment in Arrangement or Evaluation of Regional Development Plan, related to the rescue of Limboto Lake has not considered the role and interaction of the stakeholders in Gorontalo District [8]. In the final report of Strategic Environmental Assessment (SEA), Preparation of Spatial Plan of Strategic Area of Limboto Lake of Gorontalo Province in 2016-203, the Government faces difficulties, especially the limitations of secondary data or institutional data in the pre-scoping stage baseline data, on the grounds that the presence of stakeholders during the scoping workshop is not as expected [9]. Therefore, the public asset management activities of the Gorontalo Regency Government, in terms of control of the Limboto Lake management program have not yet been optimal in involving the inter-governmental, private and communitybased collaborative roles. The pattern of interaction in the management of Lake Limboto is still limited to the environment of the Gorontalo Provincial Government. On the other hand, the increasingly critical condition of Limboto Lake, as seen in the following photo documentation, requires the integration of roles and collaboration of all parties.

\section{Preservation}

Gorontalo regency administration has no unified program in order to carry out preservation in order to manage Limboto Lake. Preservation embodied in the revitalization of Limboto Lake or Limboto Lake Rescue Movement, is a program of Provincial Government of Gorontalo, without involving the stakeholders in Gorontalo district. Activities aimed at controlling sedimentation rate through tree planting along the upper watersheds Bone Bolango and Limboto, and maintaining the stability of the water volume of the lake through the construction of floodgates, maintaining the water area of the lake through the construction of embankments, developing ecotourism, and maintaining fish populations through stocking of seedlings, interaction patterns partially and sectorally, less optimize the role of society around the Limboto Lake.

The relevant institutions, such as the Department of Public Works service of Gorontalo, BPDAS, Division of Environmental Assessment and Environmental Management Agency of Gorontalo, Limboto Lake 
preservation activities tend to be partial because without coordination with the Government of Gorontalo district, and communities around Limboto Lake. Likewise, in the case of Limboto Lake management cooperation is implemented by each institution concerned which is regulated in the Standard Operational Procedure (SOP).

The proposal of one of the environmental NGOs in 2007, on a synergistic management system to see the Limboto Lake problem as a whole geographically, ecologically and culturally by releasing state administrative and territorial attributes, is poured only in the form of the Provincial Regulation of Gorontalo, and not implemented well. Whereas $60 \%$ of the residents of Gorontalo Regency live and depend on Limboto lake bioregion. The demand for the preservation of Limboto Lake is very urgent, considering that there are 23 rivers that empty into the lake as a major contributor to silting and reducing the area of the lake each year, in addition to the negative impacts of cultivation activities that can degrade the socio-economic quality of the social culture and the environment of the region. It shows that the management of public assets in Local Government of Gorontalo is necessary to maintain managing Limboto Lake optimally which involves the inter-governmental, private and community-based collaborative role.

\section{CONCLUSION}

Actors' role as a pillar of development in answering and solving public problems including Limboto lake management was not as expected. The public management paradigm prevailing within the Governmental organization has not been fully established as the basis of managing reliable asset to manage local uniqueness in order to improve people's welfare and regional growth. The Management of Limboto Lake's public asset has not been based on a public administration paradigm that emphasizes The New Public Management (NPM). Consolidation through FGDs has been held which involving institutions in Provincial level, so that generate the signing of management agreement of Limboto Lake between Government District and City of Gorontalo but it has not been used as the momentum of public asset management implementation. The planning, arrangement, control, and preservation that is the core of public asset management has not been used as a means of solving the case of Limboto Lake management effectively, efficiently and rationally.

\section{REFERENCES}

[1] Regional Regulation No. 1, on the Management of Lake Limboto, 2008.

[2] R. Dako, Approach Bioregionalism. In Rescue Effort Limboto Lake, a concept paper JAPESDA input for preparation of regional regulation Rescue for Limboto Lake Gorontalo Province, (Pendekatan Bioregionalism Dalam Upaya Penyelamatan Danau Limboto, sebuah masukan untuk kertas Konsep JAPESDA Bagi Penyusunan Peraturan Daerah Penyelamatan Danau Limboto Provinsi Gorontalo )2016.

[3] J.W. Creswell, "Research Design Approach Quantitative Qualitative and Mixed", Third Edition, First Edition, Yogyakarta: Student Library, 2010.

[4] Law No. 25 on National Development Planning System (Sistem Perencanaan Pembangunan Nasional or SPPN), 2004.
[5] Government Regulation No. 8, on Stages, Procedures for Preparation, Control and Evaluation of the Implementation Plan for Regional Development (Tahapan, Tata Cara Penyusunan, Pengendalian dan Evaluasi Pelaksanaan Rencana pembangunan Daerah), 2008.

[6] Public Works and Housing Provincial People Gorontalo, 2016 Regulation No. 26, concerning Approach to Local Development Plan Preparation, 2006.

[7] Regional Regulation No. 4 on Spatial Planning Gorontalo Province (Rencana Tata Ruang Wilayah Provinsi Gorontalo) from 2010 to 2030, 2011.

[8] Minister Regulation No. 67, on the Guidelines for Strategic Environmental Assessment in arrangement or evaluation of the Regional Development Plan (Peraturan Menteri Dalam Negeri Nomor 67 tahun 2012, tentang Pedoman Pelaksanaan Kajian Lingkungan Hidup Strategis dalam Peyusunan atau Evaluasi Rencana Pembangunan Daerah), 2012.

[9] Report of the Strategic Environmental Assessment (SEA), Department of Public Work and Housing, Provincial Gorontalo, 2016

[10] Law No. 32, on the Protection and Environmental Management, 2009 